\title{
THE CHANGING COMMODITY MARKETS - WORK ON EU REGULATIONS
}

\author{
[Měnící se komoditní trhy - práce na předpisech EU] \\ Jan Żelazny ${ }^{1}$ \\ ${ }^{1}$ University of Lodz, Department of International Economics, P.O.W. 3/5, Lodz, 90-255, Poland \\ E-mail: jan.zelazny@uni.lodz.pl
}

\begin{abstract}
Commodity markets are substantial for the shape of the world economy and experienced numerous structural changes over the span of last decades. The financial sector of the economy started to play the commanding role. The prices became more volatile as more and more financial investors began to speculate on commodity markets. Such process combined with other crucial factors leads to market abuses, decreasing transparency of trade and excessive speculation. These issues surged and were mostly observed during the subprime mortgage crisis and in the period straight after it. The policymakers around the globe made an effort in order to diminish those effects and introduced a new policy framework towards commodity markets. This paper focuses on current works and actions taken by the European Union policymakers and their United States counterparts.
\end{abstract}

Keywords: Commodity Markets, EU Regulations, Financialisation, Surveillance Policies.

JEL classification: D53, G14, Q02

Doručeno redakci: 22.10.2014; Recenzováno: 9.11.2014; 11.12.2014; Schváleno k publikování: 27.5.2015

\section{Introduction}

Commodity markets and trading of commodities are broadly recognised in economics and their significant role in the shape and growth of world economy is undoubted. Commodity markets just like the economies and financial markets have experienced numerous structural changes over the last few years. Dynamic fluctuations of commodity prices were observed in the first decade of XXI century.

Moreover, the commodity prices play important role, in particular for developing countries that are often dependent on the import of basic commodities such as food and fuel. That is why the implications empowered by dynamic commodity price changes (price volatility) may be harmful for the food and energy supply, economic development and even poverty in those countries. This has been especially visible in the recent food crises when the food prices in 2007/08 soared. The prices of main agricultural commodities such as wheat, rice, corn and soybeans doubled (FAO, 2009). Not only this type of commodities observed severe price changes, but also other like precious metals, crude oil or natural gas (IMF, 2013). Such volatility can lead to major difficulties in managing business operations as well as whole economies, especially the least developed ones (UNCTAD, 2012).

The arising price volatility and decreasing market transparency create an urge in creating surveillance policies for commodity markets. The purpose of this article is to present and review the current works and actions taken by the European Union policymakers with reference to their United States counterparts. This paper bases on initiatives and regulations proposed by the Expert Group on Agricultural Commodity Derivatives and Spot Markets working by the European Commission and the Commodity Derivatives Task Force functioning within the European Securities and Markets Authority. On the other hand, for the 
US framework the Commodity Future Trading Commission and Securities Exchange Commission activity was used as a reference.

\section{Structural changes in the world economy and commodity markets}

Over the span of last decades the world economy has been a subject for numerous structural changes. The role of the markets in the economies increased while the governmental sector lessened. The governmental sector in the economies decreased while the role of the markets has surged. Global trade boosted ninefold from 4.1 trillion USD in 1980 to 36.9 trillion USD in 2012 (own calculations based on a database of World Trade Organisation (2013)). The financial markets also commenced to be more significant, thus from 1990 until 2010 the outstanding amount of assets on equity and bond markets quadrupled. Beside the total value of those assets, their relation towards gross domestic product (GDP) also grew. In 1990 assets accounted for about $256 \%$ of world GDP and in 2010 it was already $356 \%$ of the world GDP (Roxburgh et al., 2011).

In economic literature at least three factors can be blamed for these changes are occurring most commonly. These are globalisation, neoliberalism and financialisation. While the first two drivers are broadly spoken in literature, there are still not so many discussions regarding financialisation. In recent years various professors have taken an attempt to define this new term.

According to Stockhammer (2010) under financialisation there are hidden numerous issues such as increasing debts of households, growing earnings from financial operations or worldwide surge in mobility of capital. Falkowski (2011) on the other hand describes it as a term used to describe the changes of relations between the real and financial sector in economy where the latter starts to play the commanding role. Another interesting definition was created by Krippner (2005), according to whom financialisation should be understood as a way of accumulation of capital which profit making takes place in mainly through financial channels boosted by new financial instruments not as previously through mercantile and production channels. Nevertheless, probably the most complete definition of this term was introduced by Epstein (2005, p. 3): "it means the increasing role of financial motives, financial markets, financial actors and financial institutions in the operation of the domestic and international economies".

The changes on the commodity markets fuelled by financialisation are most visible while analysing the prices of commodities in comparison to price changes of other financial assets. Fig. 1 depicts price changes in 2002 and 2012 of three assets: the price of futures for West Texas Intermediate oil, the price of basket of the biggest European stock exchanges indices and the Standard and Poor's Goldman Sachs Commodity Index (S\&P GSCI). In 2012 a comovement of the prices can be observed while in 2002 prices varied on different levels and also to some extent in different directions. 
Figure 1: Evolution of stocks and commodity price in 2002 and 2012 comparison, $31^{\text {st }}$ January $=100$
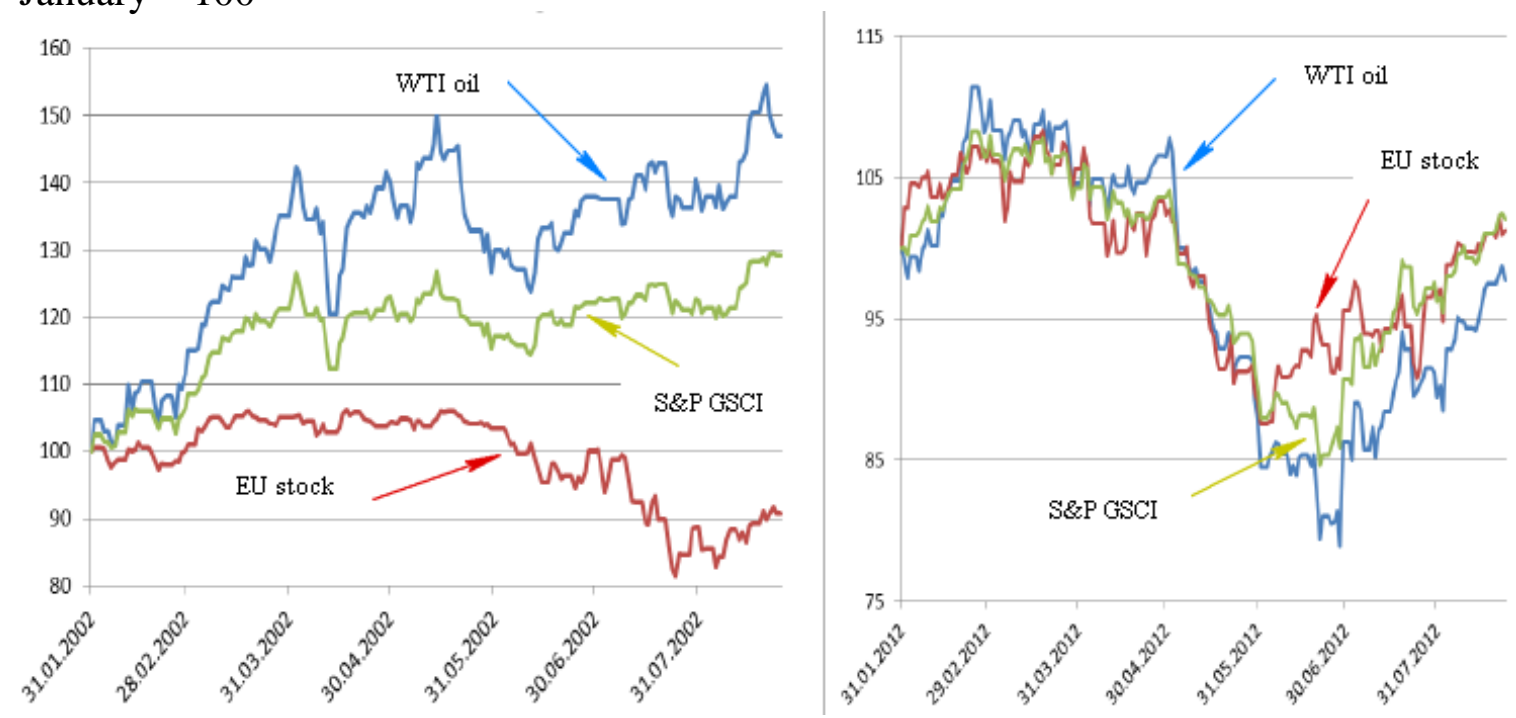

Source: Flassbeck (2013)

Despite the changing price, volumes of commodity trading rose significantly as well. Commonly used indicator to measure the size of the commodity markets is the value of open positions on commodity markets. Since 2001 the value of capital invested on commodity exchanges systematically rises. The flowing capital is allocated almost in all available types of commodities, but the most popular are those which markets present the biggest fluency, such as oil or gold. From mid 90s, in terms of the value of open positions on futures markets, WTI oil quadrupled, naturals gas surged threefold and gold grew over two times, what depicts figure 2. For other commodities presented below like copper, wheat or sugar, the value also increased.

The significant part of this growth was the effect of increasing activity of financial investors. The value of open positions represents the financial expectations of future production in time, but most of these positions are closed without the physical delivery of goods (Dwyer et al., 2011).

Figure 2: Value of open positions on commodity exchanges in years 1995-2011 (billions of USD)

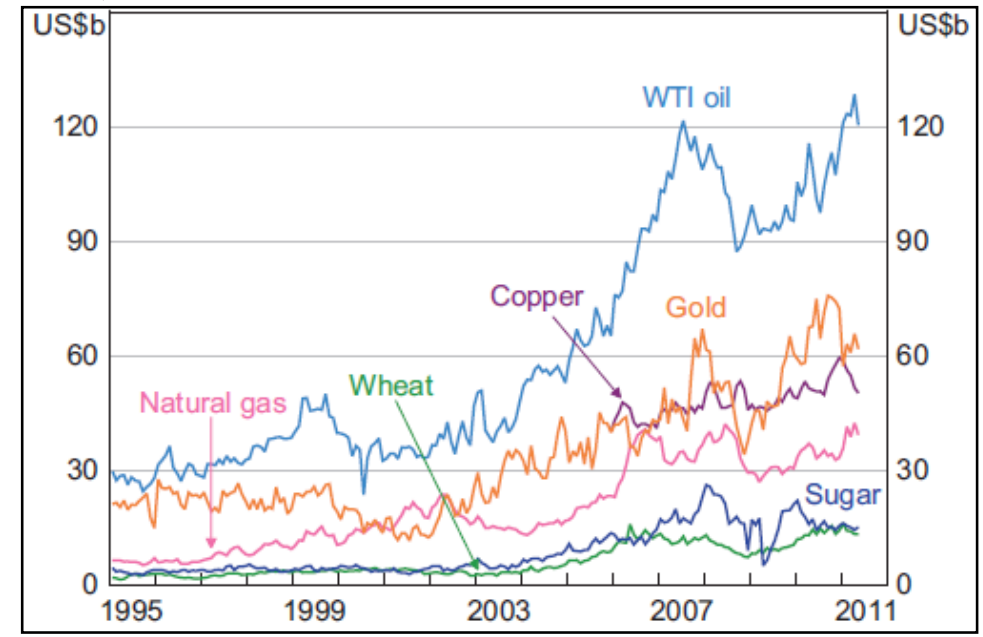

Source: Dwyer, Gardner and Williams (2011) 
Although the value of open position grew, bigger increase can be observed in terms of outstanding number of futures and options contracts on commodity exchanges what depicts figure 3. In the second part of the first decade of the XX century there was a significant and continuous rise in number of dealt contracts, from around 20 million of contracts in 2005 to 65 million in 2010. The ascending trend was only delicately upset by the financial crisis in 2007-2008. In 2011 the outstanding number of contracts was almost 50\% higher than in mid 2008 (UNCTAD, 2011).

Figure 3: Futures and options contracts outstanding on commodity exchanges, December 1993-December 2010 (number of contracts, millions)

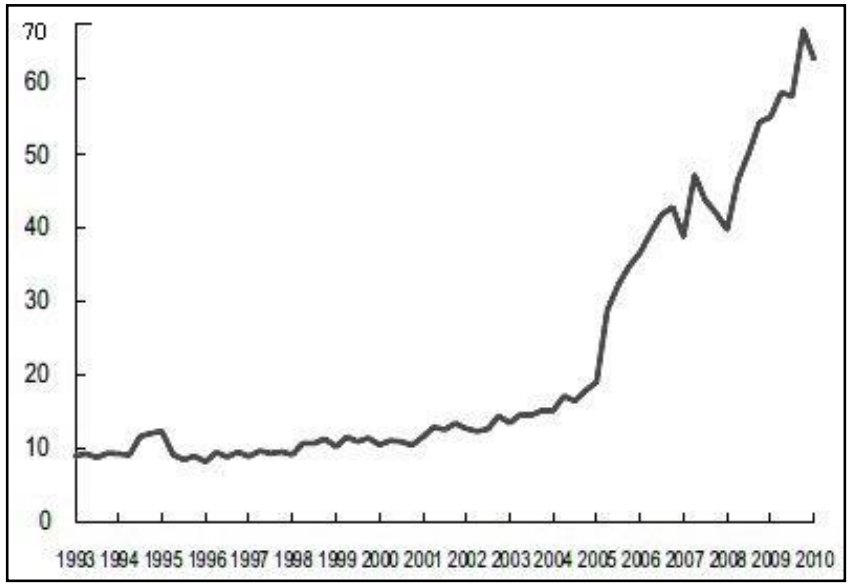

Source: United Nations Conference on Trade and Development (2011)

The notable rise of number of contracts after year 2005 was enabled by various factors, with growing presence of financial investors in commodity markets, rising value of assets in global economy or increasing demand for primary commodities named as leading ones. Nevertheless, there is also one important factor, not mentioned yet which strongly influenced the commodity trading in recent years. According to the report prepared by Dwyer, Gardner and Williams (2011) the increase of volume of opened contracts has its origins in technological changes on commodity markets, predominantly due to the development of high frequency trading - HFT with usage of algorithmic trading. HFT trading was firstly introduced on commodity exchanges in 2005, when that innovative way of trading started already to play an important role on equity markets (Bichetti and Maystre, 2012). This information can be quite well described by the data on figure 4, which presents futures contracts on WTI Oil. After introducing electronic trading, the volume of contracts increased over three times, while in the meantime the possibility of electronic trading effected in the decrease of non-electronic trade almost two times. 
Figure 4: Trading in WTI Oil Futures (millions of contracts per month)

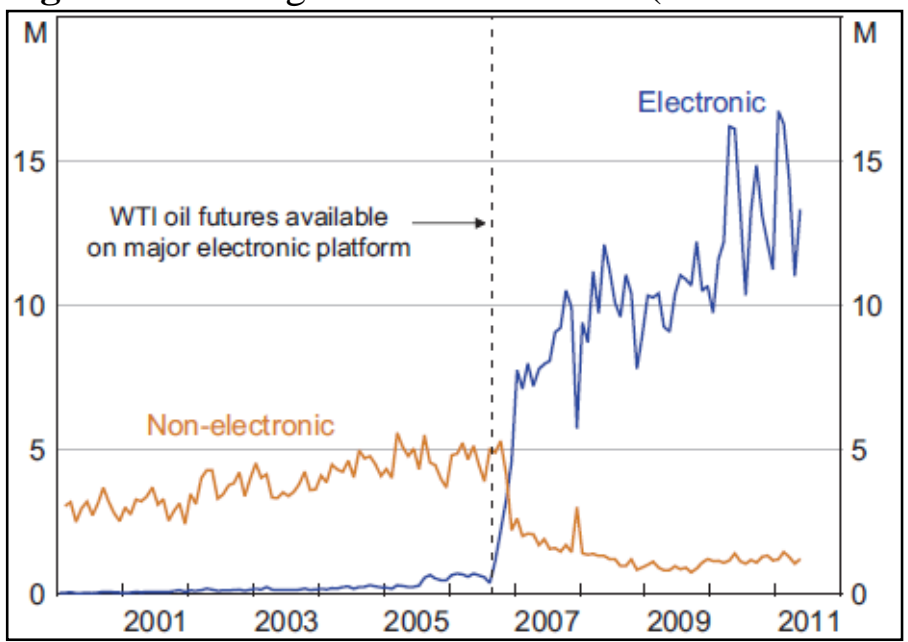

Source: Dwyer, Gardner and Williams (2011)

Financialisation is present in almost all markets in the global economy and commodity markets are not free of it either. Its influence on commodity markets is undoubted. The arising number of investors originating mainly from financial markets introduces new motives of pumping capital on the commodity markets as well as new channels of undertaking investments. This combined with ascending usage of high frequency trading (HFT) and algorithmic trading results in increasing price volatility. This new market environment raises the cost of hedging risks for traditional actors such as producers, processors or merchants. Moreover these changes lead to a decrease of market transparency (Żelazny, 2014).

Proper analyzing of trade on commodity markets requires understanding of the term of speculation, and especially the role of excessive speculation. Speculation is an inseparable part of trading on exchanges. It can be defined as the holding of a net position, either long or short, in the expectation of a positive return (Working, 1960). By that, we should note that speculation means buying an asset (here commodity) not for current consumption, but for future use from economic point of view due to anticipating the direction of price change (Fattouh et al. 2013). On the other hand we have hedging, which means undertaking transactions in a commodity futures market for reasons related to the use of physical commodities in company's (hedgers') operations, including processing, merchandising, and marketing of the commodity (Alquist and Gervais, 2013). As emphasised by Staritz and Küblböc (2013), speculation itself is necessary to maintain functioning of commodity markets, and enable hedging activities, simply to be the counterparty for hedgers. Nevertheless, an inadequate or excessive level of speculation (exceeding the need of traditional hedgers) may lead to distortions of price dynamics that may cause problems. Quantifying excessive speculation is not easy, as there is no clear indication of such practices. Determining, whether speculation is excessive does not depend on who engages in speculation, rather on volumes of trade but it is also not clear to what extent, since big operators can trade high volumes of commodities. Fattouh et al. (2013) underlines, that there is no operational definition of excessive speculation, although in public debate it is considered as self-explanatory. Most commonly, it is named as speculation that is not required for proper functioning of the market, sometimes even recognised as market manipulation. Although, it is important to stress that speculation and manipulation are distinct phenomena and that increased financialization of commodity markets does not mean that market manipulation increases. According to Fattouh et al. (2013), there is no widespread evidence of market manipulation in recent years. 


\section{Creating new regulations within the European Union}

While the world economy flourished with recovery after the dotcom bubble crisis in 2001 and 2002 (which affected mainly the developed countries), there was little interest to create new regulations since everything seemed to be working just fine. However, things changed after the subprime mortgage crisis in the year 2007 and 2008. The main surveillance entities from the United States and the European Union were facing severe problems with market transparency and liquidity, that is why they took a greater look in the shape of the financial and commodity markets in order to avoid similar economy disruptions. The European Union is still working on a new governance of these markets (the United States work will be described in latter parts of this paper).

Due to complexity of the European Union itself, there are two separate agencies responsible for preparation of such regulations. From one side there is the European Commission which settled a discussion board named Expert Group on Agricultural Commodity Derivatives and Spot Markets. In addition to this, there is the Commodity Derivatives Task Force teamed up by another agency - the European Securities and Markets Authority (ESMA) which was established in 2011 along with two other regulatory authorities: the European Banking Authority (EBA) and European Insurance and Occupational Pensions Authority (EIOPA). These three agencies form together the European Supervisory Authorities (ESAs). Moreover, the chairs of ESAs combined with European Central Bank Council and European Commission together form a supreme financial supervision entity the European Systemic Risk Board (ESRB) (Sutcliffe, 2013).

What is important the two agencies involved in work on commodity markets regulations exchange their findings and proposals with each other in order to create coherent regulations. What is more, several private and multinational organizations contribute to forge new governance, for example the Commodity Markets Council and International Organization of Securities Commissions.

\subsection{Current framework}

Both cash-settled and physically-settled commodity derivatives in the European Union are investments subject to MiFID. MiFID is the Markets in Financial Instruments Directive (Directive 2004/39/EC). It replaced the Investment Services Directive (ISD) accepted in 1993. MiFID was adopted in April 2004 and came into force in November 2007. The aim of this regulation was to "improve the competitiveness of EU financial markets by creating a single market for investment services and activities and ensuring a high degree of harmonised protection for investors in financial instruments, such as shares, bonds, derivatives and various structured products" (EC, 2014).

This regulation is complex and was designed to cover commodity derivatives trading, however, with an exclusion of non-financial companies which stood outside the scope of MiFID. The following non-financial companies were excluded from MiFID (EC, 2004):

- persons who only deal on own account (unless they are market makers or deal outside a regulated market or a multilateral trading facility ("MTF") as a systematic internaliser);

- persons whose main business consists of dealing on own account in commodities and/or commodity derivatives (provided they are part of a non-financial group);

- persons who deal on own account in financial instruments or who provide investment services in commodity derivatives or in other prescribed derivative contracts to clients of their main business, provided that this is an ancillary activity of their main business. 
Nevertheless, as reality during the subprime mortgage crisis reflected this regulation had flaws and did not prevent market abuses. The political leaders within the G20 summits in 2009 in Pittsburgh and in 2011 in Cannes added an important input to the urge for new legislation (EC, 2012). There was a need to curb the excessive speculation on commodity derivatives markets.

\subsection{Proposed regulations}

The new regulations based on the review of MiFID and the introduction of the European Market Infrastructure Regulation (EMIR). The MiFID II consists of: Markets in Financial Instruments Directive (MiFID) with changes and Markets in Financial Instruments Regulation (MiFIR). Beside these, there is also the Market Abuse Directive (MAD II) with Market Abuse Regulation (MAR). MiFIR states for the regulation based on the MiFID II directive, while MAR for the ones based on MAD II. What is noteworthy, both the MiFID II and MAD II were published in the Official Journal of the European Union on $12^{\text {th }}$ June 2014 and are planned to come into force in 30 months.

EMIR regulations came into force on $15^{\text {th }}$ March 2013, and the main obligations defined under EMIR are (ESMA, 2014):

- central clearing for certain classes of OTC derivatives;

- application of risk mitigation techniques for non-centrally cleared OTC derivatives;

- reporting to trade repositories;

- application of organisational, conduct of business and prudential requirements for CCPs;

- $\quad$ application of requirements for Trade repositories, including the duty to make certain data available to the public and relevant authorities.

The changes within MiFID II concern mainly the reconsideration of exemptions from the regulation, as well the scope of it (including the area of trading and position limits). In contradiction to MiFID from 2004, the exemption for entities whose main business is dealing on own account in commodity derivatives has been removed. However, there are still 15 privileged types of entities being out of scope of MiFID, all of them seem to be reasonable with regard to the traditional market traders and other similar counterparties.

The ancillary activity exemption will be retained in MiFID II, although in a slightly modified form. This exemption will be available to businesses which (EC, 2014a):

- deal on their own account in investments (but other than by executing client orders);

- provide investment services, other than dealing on own account, in commodity derivatives or emission allowances or derivatives thereof to the customers or suppliers of their main business; only to other group companies.

The above exemptions are only possible with assurance that those businesses do not apply high-frequency trading, notify annually the relevant authority that the usage of exemption is considered within above frames and ancillary to their main business.

In MiFID II, there is also a new requirement that sufficiently liquid standardised derivatives have to be traded on organised trading venues such as regulated markets (RMs), multi-lateral trading facilities (MTFs) or newly proposed category of organised trading facilities (OTFs), which can be an electronic platform. Moreover, the MiFID II extends transparency requirements to non-equities bonds, derivatives, structured finance products (SFPs), emission allowances. There is also a necessity of pre-trade transparency (trading venues to provide a bid/offer spread and depth of trading interest on a continuous basis during normal trading 
hours), as well a post-trade transparency (the trading venue must make public price, volume and time transaction executed as close to real time as technically possible).

MiFID II also regulates position limits on the markets, and describes them as "quantitative thresholds for maximum size of positions in commodity derivatives" (EC, 2014a). Along with position limits, position reporting is required for:

- members and participants of trading venues (RMs, MTFs, OTFs) to report to the trading venue their positions and those of their clients;

- trading venues:

$\circ$ to make public a weekly report of aggregate positions held by different categories of traders;

- Provide competent authorities with a complete breakdown of positions upon request;

- categories of traders: investment firms, investment funds, other financial institutions, commercial undertakings, emission allowance auction operators.

As mentioned earlier, another governance implemented is the MAD II/MAR package responsible for preventing from market abuses. In comparison to MAD, the new legislation extends the scope of regulations to (EC, 2014b):

- instruments traded solely on MTFs and the new category of OTFs (whereas today MAD applies to instruments admitted to trading on Regulated Markets only)

- related over-the-counter traded financial instruments which may impact the underlying market e.g. CDS;

- emissions allowances;

- spot commodity markets which impact financial instruments and vice versa.

Moreover, MAD II introduces an obligation for exchange of information and cooperation between financial and commodity regulators. The proposal includes suspicious transaction reporting to order and OTC transactions. In addition to that, it strengthens surveillance against market abuse since it creates a single rulebook enforced by national administrative sanctions. It requires the EU Member States to introduce criminal sanctions for international insider dealing and market manipulation.

On the other hand, overregulation of commodity trading, for example via position limits that are too broad not only can reduce the flow of information on futures market but also impede speculators access to it, diminishing the ability of the futures markets to perform their essential functions (CME, 2010). The proposed regulation from one end is an attempt in good direction, in order to curb excessive speculation, but in the same time is a bit vague, since it does not impose stiff boundaries of what is allowed and what is forbidden in commodity trading.

\section{The US experience - Dodd-Franck Act}

Apart from the European Union, also the United States surveillance authorities worked on market regulations after the subprime mortgage crisis in 2007/2008. In contradiction to the EU, in the US there are only two main agencies responsible for financial markets supervisory: the U.S. Securities and Exchange Commission (SEC), and the U.S. Commodity Futures Trading Commission (CFTC).

The US policymakers, with a contribution of numerous testimonies in front of the US Congress, worked on new regulation. One of the most famous testimonies was given in June 2008 by Fadel Gheit, the Managing Director and Senior Oil Analyst for Oppenheimer \& 
Company (Irwin and Sanders, 2011): "I firmly believe that the current record oil price in excess of $\$ 135$ per barrel is inflated. I believe, based on supply and demand fundamentals, crude oil prices should not be above $\$ 60$ per barrel. There were no unexpected changes in industry fundamentals in the last 12 months, when crude oil prices were below $\$ 65$ per barrel. I cannot think of any reason that explains the run-up in crude oil price, beside excessive speculation". Basing on such opinions of experts from the markets, the policymakers created the biggest single regulation in US history, the Dodd-Frank Wall Street Reform and Consumer Protection Act, which was accepted and signed by the US President Barack Obama on the $21^{\text {st }}$ July 2010 (SEC, 2014).

This governance covered all financial and commodity markets in the US and the entity named responsible for introducing this regulation on commodity markets was the CFTC. The CFTC chairman, Gary Gensler enthusiastically described this new policy (CFTC, 2014): "The reform will - for the first time - bring comprehensive regulation to the swaps marketplace. Swap dealers will be subject to robust oversight. Standardized derivatives will be required to trade on open platforms and be submitted for clearing to central counterparties. The Commission looks forward to implementing the Dodd-Frank Act to lower risk, promote transparency and protect the American public". The Dodd-Frank Act was aimed mainly at excessive speculators. Among introduced solutions, the most important were: position limits, post-trade reporting, and mandatory clearing of all standardised OTC commodity derivatives. However, the biggest swap dealers from Wall Street found the position limits very harmful for their businesses and enforced exclusion. On $16^{\text {th }}$ May 2013 CFTC agreed on the proposal of Wall Street lobby and assured that the investment banks involved in commodity derivative markets may decide freely on the sizes and values of their positions (Cohan, 2013). This decision is contradictory to the aim of the Dodd-Frank Act, since these entities operate with vast amounts of money, often on their own accounts. Thus, the US legislation, despite being a strict regulation in the beginning, is systematically softened, due to lobby from the biggest players on commodity markets.

\section{Standardisation of OTC traded derivatives - futurisation of swaps}

The subprime mortgage crisis depicted that even the biggest investment banks can be insolvent. This was like an alarm bell for the entities involved in the commodity over-thecounter markets, since investment banks were the main counterparts on the markets, the swap dealers as the counterparty risk became visible. The commodity OTC markets observed an immediate substantial outflow of capital. The trade value decreased from over 14 trillion USD to 4 trillion USD only within the second half of 2008. Since then, the trade value have levelled between 3 and 4 trillion USD (BIS, 2014).

This capital did not vaporise but headed to regulated commodity exchanges. It became possible because many new derivatives were introduced into the markets. This contracts were not completely new, they became categorised as futures but formerly traded as swaps. This is called the futurisation of swaps. This phenomenon was broadly debated within a discussion panel held by the CFTC in January 2013 (CFTC, 2013). The futurisation of swaps brings operational benefits of ease termination of the contract and ability to use existing infrastructure and technology of commodity exchanges. Moreover it enables the avoidance of regulations related to swap dealing such as: registration as a swap dealer, fulfilling business conduct requirements and disclosing and reporting of swap data (Shilts, 2013).

Futurisation of swaps is possible, since the Dodd-Frank Act does not differentiate between swaps and futures in terms of economic uses or purposes. Futures are described as 
standardised products designed and listed by futures exchanges, cleared and traded on regulated futures exchange. Swaps under Dodd-Frank Act on the other hand can be standardised or customised and also cleared and traded either on regulated futures exchanges or on swap execution facilities. What is noteworthy, the same derivatives product can be listed as a future or a swap in the apprehension of this regulation (Shilts, 2013).

In addition to that, the biggest commodity exchanges, such as for example the CME Group constantly introduce new futurised swaps, mainly on commodity price indices. In the end of October 2012 the CME Group offered the following swaps on commodity indices (CME, 2013):

- S\&P GSCI Excess Return Index 2 Month Forward Swap,

- S\&P GSCI Excess Return Index 3 Month Forward Swap,

- S\&P GSCI Excess Return Swap,

- S\&P GSCI Enhanced Excess Return Swap,

- S\&P GSCI Gold Excess Return Swap,

- GSCI Crude Oil Excess Return Swap,

- Dow Jones-UBS Commodity Index Swap.

\section{Conclusion}

In the first decade of XXI century there were many structural changes on commodity markets. Financialisation of commodity markets appeared to be a result of numerous factors such as structural changes of the world economy, introduction of complex derivatives, abundance of cheap capital and growing willingness in trading commodities by the financial investors. In its consequences, financialisation leads to an increase in price volatility and bigger costs of hedging for traditional actors such as producers, processors or merchants. It decreased the market transparency and even may be blamed for several disruptions in food and fuel supply in the developing countries.

Establishing a new regulatory framework towards commodity markets took the European Union over six years from the beginning of the subprime mortgage crisis, and however already created, it has not yet come into force. The governance introduced by the MiFID II and MAD II directives includes position limits, fewer exemptions, pre- and post-trading reporting, obligatory clearing and many more. Undoubtedly, this new surveillance laws are justified, difficult to omit for excessive speculators and focused on assuring effective and liquid markets mostly for traditional actors.

The upcoming years will show whether the new legislation framework is effective and whether it maintains its role. It may occur that new regulations will be needed, since the commodity markets, just like the global economy, continuously evolve. It may be also just the opposite, that these newly introduced governance have overregulated the markets and to enable its proper functioning deregulation will be need. That is why more scientific studies will be needed in order to assess the results of the new regulatory framework.

\section{References}

[1] ALQUIST, R. and O. GERVAIS, 2013. The role of financial speculation in driving the price of crude oil. The Energy Journal, 34(3). ISSN 0195-6574.

[2] BANK FOR INTERNATIONAL SETTLEMENTS (BIS), 2013. Statistical Release: OTC Derivatives, Basel, various issues. 
[3] BICCHETTI, D. and N. MAYSTRE, 2012. The synchronized and long-lasting structural change on commodity markets: evidence from high frequency data. MPRA Paper [online]. No. 37486. Munich. Accessible from: http://mpra.ub.unimuenchen.de/37486/

[4] CME GROUP, 2010. Excessive Speculation and Position Limits in Energy Derivatives Markets [online]. [cit. 12 August 2014]. Accessible from: http://openmarkets.cmegroup.com/wp-content/uploads/2010/03/Excessive_Speculation_ Paper.pdf

[5] CME GROUP, 2013. Cleared OTC Commodity Index Contracts [online]. [cit. 10 August 2014]. Accessible from: http://www.cmegroup.com/trading/agricultural/files/ AC377_COM_Index_Fact_Card.pdf

[6] COHAN, W. D., 2013. Swaps Vote Is Another Big Win for the Big Banks [online]. [cit. 10 August 2014]. Accessible from: http://www.bloomberg.com/news/2013-0521/swaps-vote-is-another-big-win-for-the-big-banks.html

[7] DWYER, A., G. GARDNER and T. WILLIAMS, 2011. Global Commodity Markets Price Volatility and Financialisation. Bulletin Reserve Bank of Australia, June quarter 2011, 49-57. ISSN 0725-0320.

[8] EPSTEIN, G. A., 2005. Financialization and the World Economy. Cheltenham: Edward Elgar Publishing Limited. ISBN 9781845429652.

[9] EUROPEAN COMMISSION (EC), 2012. Financial markets regulatory reform in the EU: State of play (MiFiD, MAD, EMIR). Directorate General Internal Market and Services, for the Expert Group on Agricultural Commodity Derivatives and Spot Markets.

[10] EUROPEAN COMMISSION (EC), 2004. Markets in Financial Instruments Directive. European Commission. Directive 2004/39/EC.

[11] EUROPEAN COMMISSION (EC), 2014. European Commission websites [online] [cit. 8 August 2014]. Accessible from: http://ec.europa.eu/internal_market/ securities/isd/mifid/index_en.htm

[12] EUROPEAN COMMISSION (EC), 2014a. Markets in Financial Instruments Directive. European Commission. Directive 2014/65/EU.

[13] EUROPEAN COMMISSION (EC), 2014b. Directive on criminal sanctions for market abuse (market abuse directive). Directive 2014/57/EU.

[14] EUROPEAN SECURITIES AND MARKETS AUTHORITY (ESMA) [online] [cit. 4 August 2014]. Accessible from: http://www.esma.europa.eu/pl/page/European-MarketInfrastructure-Regulation-EMIR.

[15] FALKOWSKI, M., 2011. Financialization of Commodities. Contemporary Economics, 5(4), 4-17. ISSN 2084-0845.

[16] FATTOUH, B., L. KILIAN and L. MAHADEVA, 2013. The Role of Speculation in Oil Markets: What Have We Learned So Far? The Energy Journal, 34(3). ISSN 19449089.

[17] FLASSBECK, H., 2013. The impact of financialization on commodity prices, for the Expert Group on Agricultural Commodity Derivatives and Spot Markets [online]. [cit. 13 August 2014]. Accessible from: http://ec.europa.eu/agriculture/cereals/commodityexpert-group/ index_en.htm 
[18] FOOD AND AGRICULTURE ORGANISATION OF THE UNITED NATIONS (FAO), 2009. The state of agricultural commodity markets: High food prices and the food crisis experiences and lessons learned. Rome. ISBN 978-92-5-106280-7.

[19] INTERNATIONAL MONETARY FUND (IMF), 2013. Own calculations based on IMF databases [online]. [cit. 8 August 2014]. Accessible from: http://www.imf.org/external/np/res/commod /index.aspx

[20] IRWIN, S. H. and D. R. SANDERS, 2011. Index Funds, Financialization, and Commodity Futures Markets. Applied Economic Perspectives and Policy, 33(1), 1-31. ISSN 2040-5804.

[21] KRIPPNER, G. R., 2005. The financialization of the American economy. SocioEconomic Review, Nr. 3. ISSN 1475-147X.

[22] ROXBURGH, C., S. LUND and J. PIOTROWSKI, 2011. Mapping global capital markets 2011. New York: McKinsey Global Institute. Accessible from: http://www.mckinsey.com/insights/global_capital_markets/mapping_global_capital_mar kets_2011

[23] SHILTS, R., 2013. Transparency in agricultural commodity markets - the Dodd-Frank Act. CFTC for Expert Group on Agricultural Commodity Derivatives and Spot Markets.

[24] STARITZ, C. and K. KÜBLBÖCK, 2013. Re-regulation of commodity derivative markets - Critical assessment of current reform proposals in the EU and the US. ÖFSE Working Paper, no. 45. Vienna. Accessible from: http://www.oefse.at/en/ publications/detail/publication/show/Publication/Re-regulation-of-commodity-derivativemarkets/

[25] STOCKHAMMER, E., 2010. Financialization and the Global Economy. PERI Working Paper, 240. Amherst. Accessible from: http://www.peri.umass.edu/236/hash/ c054892e7a23115bfbd0c22c9e90f57c/publication/432/

[26] SUTCLIFFE, C., 2013, ESMA Senior Officer Secondary Markets, for the Expert Group on Agricultural Commodity Derivatives and Spot Markets [online]. [cit. 8 August 2014]. Accessible from: http://ec.europa.eu/agriculture/cereals/commodity-expert-group/index_ en.htm

[27] U. S. COMMODITY FUTURES TRADING COMMISSION (CFTC), 2013. Discussion panel: "Futurisation of Swaps" 31.01 .2013 [online]. [cit. 8 August 2014]. Accessible from: http://www.cftc.gov/PressRoom/Events/opaevent_cftcstaff013113

[28] U. S. COMMODITY FUTURES TRADING COMMISSION (CFTC) [online] [cit. 8 August 2014]. Accessible from: http://www.cftc.gov/LawRegulation/ DoddFrankAct/index.htm

[29] U.S. SECURITIES AND EXCHANGE COMMISSION (SEC) [online] [cit. 8 August 2014]. Accessible from: http://www.sec.gov/spotlight/dodd-frank.shtml

[30] UNITED NATIONS CONFERENCE ON TRADE AND DEVELOPMENT (UNCTAD), 2011. Price formation in financialized commodity markets: the role of information. New York and Geneva.

[31] UNITED NATIONS CONFERENCE ON TRADE AND DEVELOPMENT (UNCTAD), 2012. Excessive commodity price volatility: macroeconomic effects on growth and policy options. Contributions to the G20. Commodity Markets Working Group. Geneva. 
[32] WORKING, H., 1960. Speculation on Hedging Markets. Food Research Institute Studies, 1(2), 185-220. Accessible from: http://purl.umn.edu/136578

[33] WORLD TRADE ORGANIZATION [online] [cit. 8 August 2014]. Accessible from: http://stat.wto.org/Home/WSDBHome.aspx?Language $=$

[34] ŻELAZNY, J., 2014. Financialisation of commodity markets. In: Conference proceedings from the $10^{\text {th }}$ International Bata Conference. Zlin: UTB, FaME. ISBN 97880-7454-339-5. 